Original Research Paper

\title{
Winter Forage Program Benefitted Small-Scale Goat Producers
}

\author{
${ }^{1}$ Uma Karki and ${ }^{2}$ Lila Bahadur Karki \\ ${ }^{1}$ Agricultural and Environmental Sciences/Cooperative Extension, Tuskegee University, United States \\ ${ }^{2}$ Cooperative Extension, Tuskegee University, United States
}

\author{
Article history \\ Received: 23-12-2016 \\ Revised: $10-05-2017$ \\ Accepted: 12-06-2017 \\ Corresponding Author: \\ Uma Karki \\ Agricultural and Environmental \\ Sciences/Cooperative \\ Extension, Tuskegee \\ University, United States \\ Email: karkiu@mytu.tuskegee.edu
}

\begin{abstract}
Small and limited resource farmers are raising goats on pastures in the southeast USA. Nevertheless, many of these farms do not have productive and quality pastures to support the nutrient requirements of their animals. Information on forages that are suitable to improve goat pastures and sustainably grazing those pastures with goats is still lacking. Study objectives were to (1) find winter forages suitable for goats, (2) evaluate the productivity and quality of these forages and (3) assess the benefits farmers would receive from pasture improvement and grazing management. Two separate studies were conducted, one in Selma and another in Phenix City, Alabama, USA in 2012 and 2013 (September/October-April). Each study was designed as a randomized complete block with three replications. Five legumes: Arrowleaf clover (Trifolium vesiculosum Savi), berseem clover (Trifolium alexandrinum L.), crimson clover (Trifolium incarnatum L.), hairy vetch (Vicia villosa Roth) and winter peas (Pisum sativum L.) were grown with Marshall ryegrass (Lolium multiflorum Lam.) in 40:60 legume:grass ratio on separate strips. A sole Marshall ryegrass strip was planted as a control. Goats' preference for and productivity and quality of forages and benefits associated with winter pasture and grazing were evaluated. Goats readily grazed all forages but winter peas at the very first exposure; from the second exposure onwards, goats grazed winter peas well. The mixtures of crimson clover and Marshall ryegrass and hairy vetch and Marshall ryegrass produced the most. The cost of goat production was significantly reduced because of the development and management of winter pastures. Raising goats on pastures can be much more beneficial than raising them on purchased feeds.
\end{abstract}

Keywords: Economic Benefits, Goat Producers, Legumes, Pastures, Rotational Grazing

\section{Introduction}

Raising meat goat is becoming popular among the small and limited resource farmers as a part-time business, since it requires a low initial investment in comparison to many other agricultural enterprises. Moreover, because of goats' smaller size compared to large ruminants, retirees or people approaching the retirement age are feeling comfortable with goat farming and initiating this enterprise to continue their active life and get some side income. Goat meat has a niche market for different ethnic and faith-based groups: Asians, Hispanics, Africans, Muslims and people from the Caribbean (Kebede, 2005). This market is growing with the increasing ethnic population (Jones, 2003; Solaiman, 2007). According to USCB (2012), future demand for goat meat in the United States is expected to increase greatly as Hispanics and Asians are projected to share U.S. population by 33 and $8 \%$ respectively.

Despite the increasing popularity and market of meat goats, the production practices are still not very sustainable. One important reason for this is poor pastures that eventually lead to a high production cost. Most of the producers do not have a good pasture improvement and management program and thus they need to depend on hay or commercial feeds to sustain their goats for about five to six months from late fall to late winter or early spring. Supplementary feeding is more costly than grazing because of costs involved in purchased feeds and storage facilities, additional time involved in feeding goats and loss of feedstuff during storage and feeding. Ball et al. (2007) highlighted that 
$30 \%$ or higher hay dry matter may be lost when kept out without any cover in the fields. Fifty percent or higher loss of hay dry matter can occur during storage and feeding (Kallenbach, 2000).

The high cost of production can be minimized by developing winter pastures and managing them sustainably. However, not much information is available on suitable forage species that are preferred by goats and can be grown well in different locations. Mostly, farmers depend on the existing pastures to feed their animals and hesitate to introduce new forage species. From different farm visits and communication with the producers, the authors found that goat producers were spending a lot on purchased feed, such as hay and commercially prepared goat feed. Most producers initiated goat farming before developing good pastures required to sustain their goats. Mostly, producers depend on the existing pastures and hesitate to introduce new forage species, especially legumes. There were several reasons for this reluctance: (1) farmers were not sure which forage species, especially legumes, were readily eaten by goats, (2) they did not know which forage species would be most suitable for the soil and environmental condition of their pastureland, (3) most farmers did not have established facilities for a rotational grazing system, which is required for the sustainable management of most of the multi-species pastures such as those that involve different species of grass and legumes, (4) costs involved for the required inputs and facility establishment and (5) farmers were not sure whether the enhanced pasture and rotational grazing management would benefit them significantly after making all the required spending and time involvement.

The current study was conducted to accomplish three objectives: (1) To find suitable winter forages for goats, (2) to evaluate the productivity and quality of these forages and (3) to assess the benefits farmers would receive from pasture improvement and grazing management.

\section{Methods}

\section{Study Site, Design and Treatment}

The study was conducted in Selma $\left(32^{\circ} 27^{\prime} \mathrm{N}\right.$, $86^{\circ} 57^{\prime} \mathrm{W}, 39.6 \mathrm{~m}$ asl) and Phenix City $\left(32^{\circ} 25^{\prime} \mathrm{N}\right.$, $85^{\circ} 01^{\prime} \mathrm{W}, 148 \mathrm{~m}$ asl), Alabama, USA, by involving cooperator farmers. Both sites had the 'sandy' and 'loams and light clays' type of soil (Selma: Bama fine sandy loam with 0-3\% slope; Phenix City: TroupSpringhill-Luverne complex with $10-30 \%$ slopes and Troup-Alaga complex with $0-5 \%$ slopes). The study design was randomized complete block having three replications at both sites. Forage treatments (5) and Marshall ryegrass (Lolium multiflorum Lam.) control were randomly allocated to strips (6) within each replication. Treatment consisted of a mixture of Marshall ryegrass with one of the five legumes:
Arrowleaf clover (Trifolium vesiculosum Savi), berseem clover (Trifolium alexandrinum L.), crimson clover (Trifolium incarnatum L.), hairy vetch (Vicia villosa Roth) and winter peas (Pisum sativum L.)

\section{Land Preparation and Forage Cultivation}

Required lime (2.24-4.48 $\mathrm{t} \mathrm{ha}^{-1}$ ) based on a soil test was applied at least three months prior to the planting date. Weeds were controlled with the close grazing by goats and mowing. The soil was tilled with light disking and forage seeds were planted using no-till drill (Selma) or manually spread (Phenix City) in late September to early October of 2011 and 2012. The recommended phosphorus (45-90 $\mathrm{kg} \mathrm{ha}^{-1}$ ) and potassium (45-112 kg $\mathrm{ha}^{-1}$ ) fertilizers were applied at the time of planting. Forage treatments consisted of legume-grass mixture with $40 \%$ legume and $60 \%$ grass seeds. Nitrogen fertilizer was applied only to the control strip based on the soil test recommendation (67-112 $\left.\mathrm{kg} \mathrm{ha}^{-1}\right)$.

\section{Sample Collection and Grazing Management}

Pastures at each site were cross-fenced to establish three paddocks, which ranged from 0.81 ha (Selma) to 0.61 ha (Phenix City). When forages were well established (90-100 days from planting) and reached the grazing height $(\geq 25.40 \mathrm{~cm}$; Ball et al., 2007), forage samples were collected to determine the dry matter and quality before each grazing rotation during the grazing study period that occurred in the cool-season of 2012 and 2013 (December/January-April). Three samples per strip were collected by clipping forages contained in $0.25 \mathrm{~m}^{2}$ quadrat to $5 \mathrm{~cm}$. Forage dry matter was determined by drying samples at $60^{\circ} \mathrm{C}$ for $72 \mathrm{~h}$ and weighing. Dried samples were ground through 2-mm mesh and analyzed for quality (Acid Detergent Fiber (ADF) and nitrogen) (Goering and Van Soest, 1970). Crude protein content of forages was calculated by multiplying the nitrogen content with 6.25 .

After collecting samples, paddocks were rotationally grazed with goats the cooperator farmers had at that time. Selma site had few Kikos and Nubians and mostly Boers (40 mature goats) and Phenix City site had few Boers and crosses of Kiko, Spanish, or Boer (35 mature goats). Fresh water and complete mineral mix were continuously supplied to each paddock for the goats. Before and after each grazing, measurements were taken on forage and stubble heights. Farmers contributed to each activity of the on-farm research and they took care of the day-to-day grazing and caring for the animals.

\section{Economic Assessment}

Records of expenses for the goat operations and establishing and managing pastures were kept from October 2011 to May 2012 at both study sites using a pre-structured record-keeping format. Farmers were interviewed about additional advantages they 
experienced after pasture improvement, such as reduction in labor requirements, decrease in the health and parasite problems in goats and better animal performance. Cost savings due to fewer hours of labor requirements in taking care of goats were calculated by multiplying the number of hours saved with the minimum U.S. federal rate of pay $\left(\$ 7.25 \mathrm{hr}^{-1}\right)$. The estimation of the nitrogen amount fixed by forage legumes was made by taking the reference of relevant literature (Ball et al., 2007) and the monetary value of the fixed nitrogen was calculated by using the USDA-ERS (2013) price for nitrogen fertilizer for 2012. Savings in feeding costs were calculated by subtracting the costs for purchased feeds for the period of grazing on cool-season forages (January-May, 2012) from the similar costs before winter pastures were available for grazing (October-December, 2011).

\section{Data Analysis}

Mixed model (SAS 9.3) was used to analyze forage biomass data; block was assigned as 'random' and sampling sequence 'repeated' factors (Littell et al., 2006). The main sources of variation were treatment and sampling sequence and the alpha probability level was set at 0.05 to reject the $\mathrm{H}_{0}$ (null hypothesis). Mixed model was also used to analyze the forage quality and height data, but without the repeated factor. Data that did not satisfy the assumption of normal distribution were power transformed for analysis and means were back transformed to the original units.
With such means, Confidence Intervals $(\mathrm{CI})$ were used as measures of dispersions.

\section{Results}

\section{Suitable Winter Forages for Goats}

Throughout the grazing studies, goats consumed forages from all treatments well from the very first exposure other than winter peas, which was also readily eaten by goats from the second exposure (Fig. 1 and 2).

\section{Forage Productivity and Quality}

Among the treatments in Selma, crimson cloverMarshall ryegrass $\left(1.76 \mathrm{t} \mathrm{ha}^{-1}\right)$ and hairy vetch-Marshall ryegrass $\left(1.71 \mathrm{t} \mathrm{ha}^{-1}\right)$ produced the highest amount of biomass (Fig. 3). Berseem clover-Marshall ryegrass treatment showed lower crude protein $\left(115 \pm 10.9 \mathrm{~g} \mathrm{~kg}^{-1}\right)$ compared to other grass-legume treatments $(\geq 147 \pm 10.9 \mathrm{~g}$ $\mathrm{kg}^{-1}$ ) (Table 1).

In Phenix City, crimson clover produced a higher biomass than arrowleaf and berseem clovers (Fig. 4). However, the total biomass was not different among the treatments. Crude protein content of crimson clover-Marshall ryegrass $\left(168 \pm 10.2 \mathrm{~g} \mathrm{~kg}^{-1}\right)$ and winter peas-Marshall ryegrass $\left(170 \pm 10.2 \mathrm{~g} \mathrm{~kg}^{-1}\right)$ treatments remained higher than that of sole Marshall ryegrass

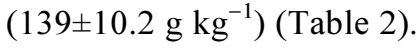

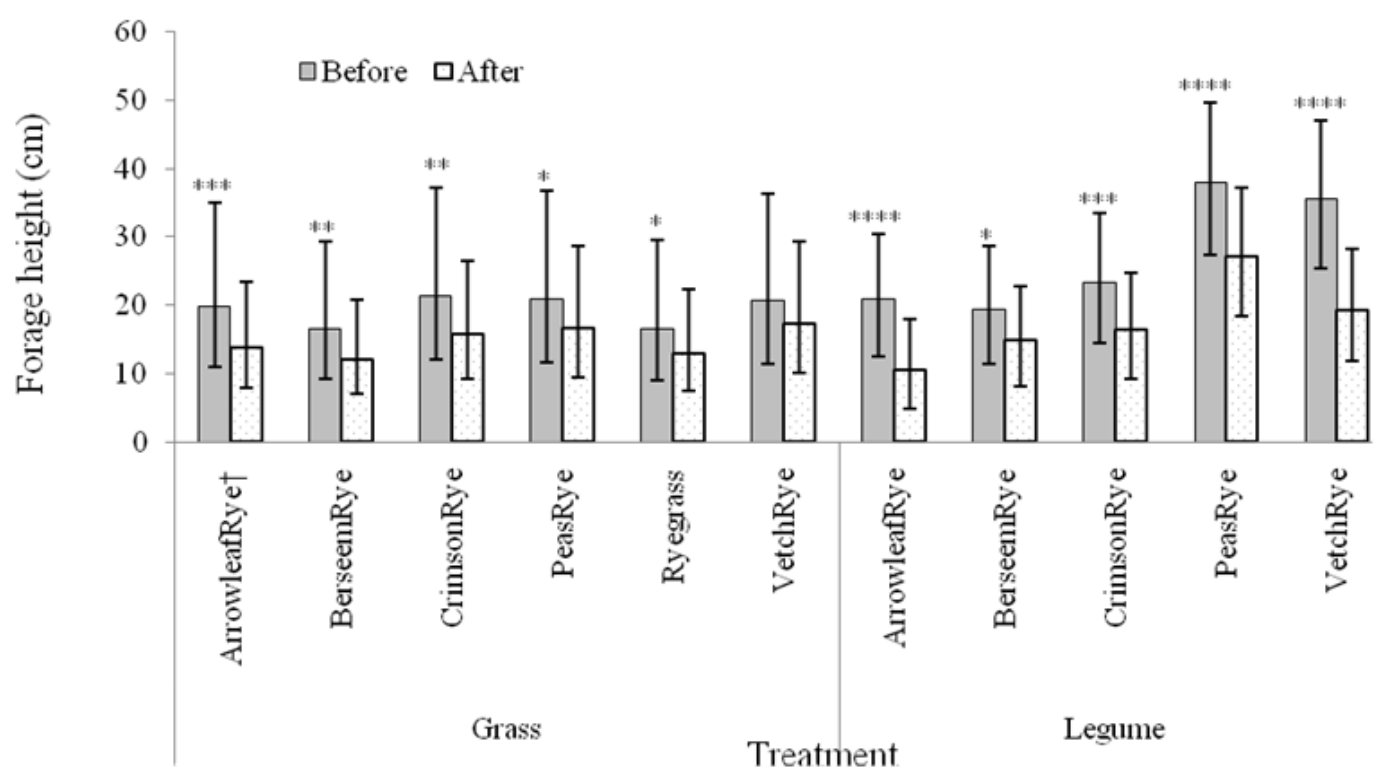

Fig. 1. Height of forages (Least-squares means \pm CI) from different treatments before and after grazing, 2012-2013 (Jan.-Apr.), Selma, Alabama, United States; ****p $<0.0001, * * * \mathrm{p}<0.001, * * \mathrm{p}<0.01, * \mathrm{p}<0.05$; ArrowleafRye $=$ Arrowleaf clover (Trifolium vesiculosum Savi) -Marshall ryegrass (Lolium multiflorum Lam.); BerseemRye $=$ Berseem clover (Trifolium alexandrinum L.) -Marshall ryegrass; CrimsonRye = Crimson clover (Trifolium incarnatum L.) -Marshall ryegrass; PeasRye $=$ Winter peas (Pisum sativum L.) -Marshall ryegrass; VetchRye = Hairy vetch (Vicia villosa Roth) -Marshall ryegrass 


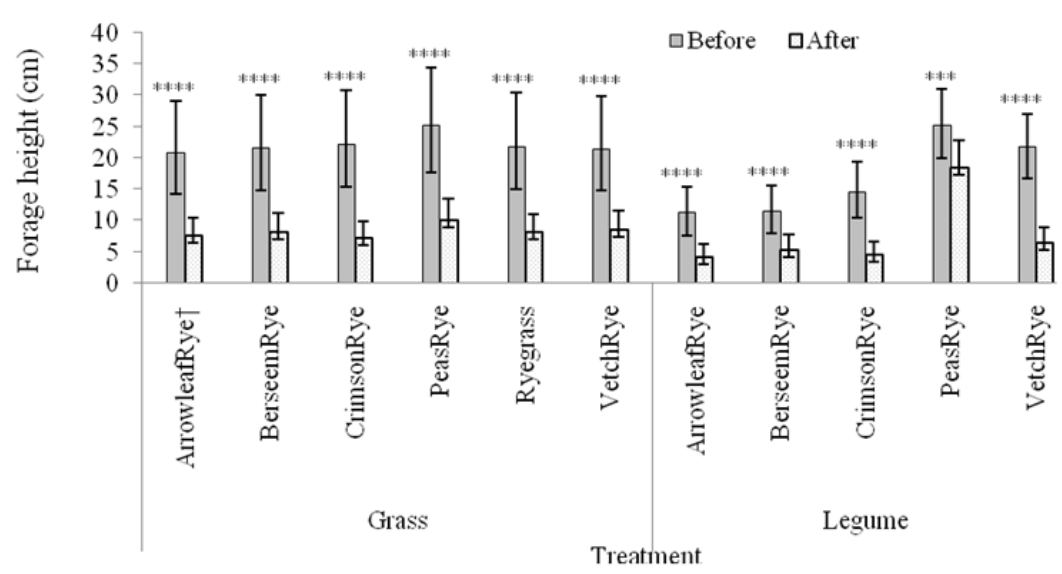

Fig. 2. Height (Least-squares means $\pm \mathrm{CI}$ ) of forages from different treatments measured before and after grazing, $2012-2013$ (Dec. or Jan.-Apr.), Phenix city, Alabama, United States; ${ }^{* * * * p}<0.0001, * * * \mathrm{p}<0.001$

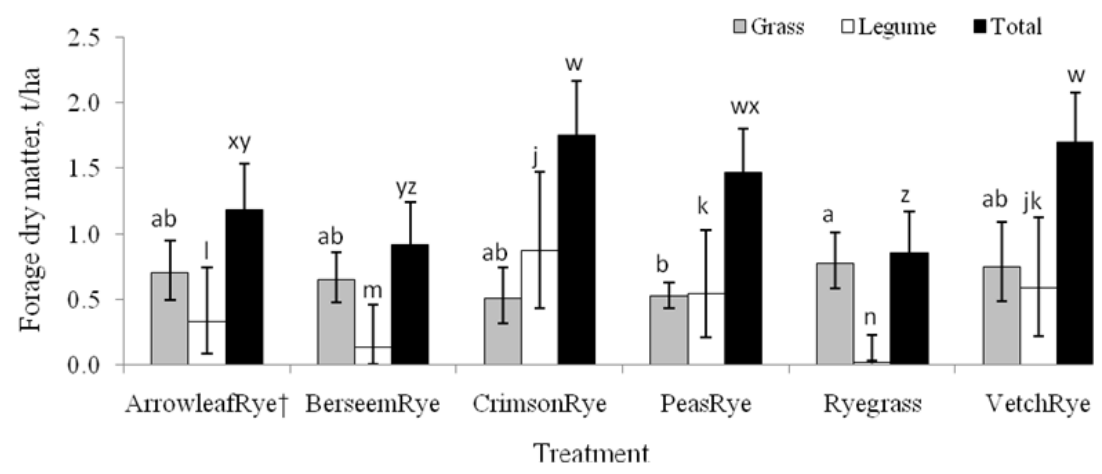

Fig. 3. Forage Dry Matter (FDM*) (Least-squares means \pm CI) for different treatments, 2012-2013 (Jan.-Apr.), Selma, Alabama, United States; *FDM with different letters for the same forage category [Grass-abc, Legume-jklmn, or Total-wxyz] are different $[\mathrm{p}<0.05]$ ); $\uparrow$ ArrowleafRye, Arrowleaf clover (Trifolium vesiculosum Savi)-Marshall ryegrass (Lolium multiflorum Lam.); BerseemRye, Berseem clover (Trifolium alexandrinum L.) -Marshall ryegrass; CrimsonRye, Crimson clover (Trifolium incarnatum L.) -Marshall ryegrass; PeasRye, winter peas (Pisum sativum L.) -Marshall ryegrass; Ryegrass, Marshall ryegrass; VetchRye, Hairy vetch (Vicia villosa Roth) -Marshall ryegrass

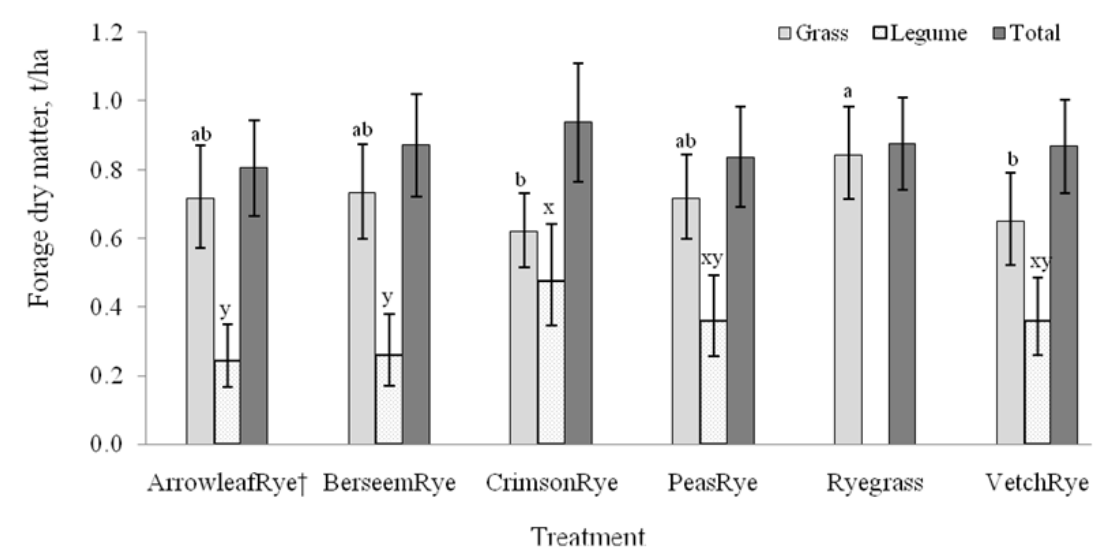

Fig. 4. Forage Dry Matter (SDM) (Least-squares means \pm CI) for different treatments, 2012-2013 (Jan.-Apr.), Phenix City, Alabama, United States; ${ }^{\dagger}$ ArrowleafRye $=$ Arrowleaf clover (Trifolium vesiculosum Savi) -Marshall ryegrass (Lolium multiflorum Lam.); BerseemRye $=$ Berseem clover (Trifolium alexandrinum L.) - Marshall ryegrass; CrimsonRye $=$ Crimson clover (Trifolium incarnatum L.) -Marshall ryegrass; PeasRye = Winter peas (Pisum sativum L.) -Marshall ryegrass; VetchRye = Hairy vetch (Vicia villosa Roth) -Marshall ryegrass 
Table 1. Quality (Least-squares means \pm SE) of forages from different treatments, 2012-2013 (Jan.-Apr.), Selma, Alabama, United States

\begin{tabular}{|c|c|c|}
\hline \multirow[b]{2}{*}{ Forage type } & \multicolumn{2}{|c|}{ Forage quality $\mathrm{g} \mathrm{kg}^{-1}$} \\
\hline & $\mathrm{ADF}^{*}$ & $\mathrm{CP} \uparrow$ \\
\hline Arrowleaf clover (Trifolium vesiculosum Savi) -Marshall ryegrass (Lolium multiflorum Lam.) & $219 \pm 17.4$ & $147 \pm 10.9^{\mathrm{a}}$ \\
\hline Berseem clover (Trifolium alexandrinum L.) -Marshall ryegrass & $194 \pm 17.4$ & $115 \pm 10.9^{\mathrm{b}}$ \\
\hline Crimson clover (Trifolium incarnatum L.) -Marshall ryegrass & $228 \pm 17.4$ & $157 \pm 10.9^{\mathrm{a}}$ \\
\hline Winter peas (Pisum sativum L.) -Marshall ryegrass & $229 \pm 17.4$ & $155 \pm 10.9^{\mathrm{a}}$ \\
\hline Marshall ryegrass & $215 \pm 17.4$ & $134 \pm 10.9^{\mathrm{ab}}$ \\
\hline Hairy vetch (Vicia villosa Roth) -Marshall ryegrass & $241 \pm 17.4$ & $163 \pm 10.9^{\mathrm{a}}$ \\
\hline
\end{tabular}

Table 2. Forage quality (Least-squares means \pm SE) for different treatments, 2012-2013 (Dec. or Jan.-Apr.), Phenix City, Alabama, United States

\begin{tabular}{|c|c|c|}
\hline \multirow[b]{2}{*}{ Forage type } & \multicolumn{2}{|c|}{ Forage quality $\mathrm{g} \mathrm{kg}^{-1}$} \\
\hline & $\mathrm{ADF}^{*}$ & $\mathrm{CP} \dagger$ \\
\hline Arrowleaf clover (Trifolium vesiculosum Savi) -Marshall ryegrass (Lolium multiflorum Lam.) & $215 \pm 18.0$ & $145 \pm 10.2^{\mathrm{ab}} t$ \\
\hline Berseem clover (Trifolium alexandrinum L.) -Marshall ryegrass & $224 \pm 18.0$ & $153 \pm 10.2^{\mathrm{ab}}$ \\
\hline Crimson clover (Trifolium incarnatum L.) -Marshall ryegrass & $217 \pm 18.0$ & $168 \pm 10.2^{\mathrm{a}}$ \\
\hline Winter peas (Pisum sativum L.) -Marshall ryegrass & $233 \pm 18.0$ & $170 \pm 10.2^{\mathrm{a}}$ \\
\hline Marshall ryegrass & $222 \pm 18.0$ & $139 \pm 10.2^{b}$ \\
\hline Hairy vetch (Vicia villosa Roth)-Marshall ryegrass & $226 \pm 18.0$ & $166 \pm 10.2^{\mathrm{ab}}$ \\
\hline
\end{tabular}

*ADF-Acid detergent fiber; $\uparrow$ CP-Crude protein; $\$$ Least-squares means in a column followed by different superscripts differ $(p<0.05)$

Table 3. Economic benefits of developing winter pastures for goats during the 2012 cool-season grazing period, Selma and Phenix City, Alabama, United States

\begin{tabular}{lcr}
\hline & Study site costs or benefits (US \$) & Phenix city \\
Savings in production costs & Selma & 1,196 \\
\hline Labor savings & 1,196 & 271 \\
Savings in fertilizer costs because of N fixation & 361 & 1,303 \\
Savings in feeding costs & 1,215 & 2,770 \\
Sub-total (A) & 2,772 & 321 \\
Pasture establishment costs & & 150 \\
Soil testing and liming & 293 & 685 \\
Land preparation and planting & 162 & 183 \\
Fertilizers & 536 & 1,339 \\
Forage seeds & 244 & 1,431 \\
Sub-total (B) & 1,235 & 1,537 \\
Total benefits (A-B) & &
\end{tabular}

By developing winter pastures, farmers at both study sites were able to reduce goat-production costs by $\$ 1431$ or more (Table 3). Both farmers saved at least one hour each in labor requirements per day for taking care of goats because of cool-season pastures. Moreover, they expressed that goat performance was improved and health and parasite problems reduced because of the availability of high-quality forages for grazing during winter versus the previous winter.

\section{Discussion}

From the very beginning, goats readily grazed all forages but the winter peas, which were grazed well from the second exposure, indicating that all these forages can be considered for developing winter pastures for goats. Higher productivity of most legume-Marshall ryegrass combinations, except berseem clover-Marshall ryegrass treatment, compared to the sole Marshall ryegrass found at the Selma study site is in agreement with previous findings. Karki et al. (2009) found a 40\% increase in the productivity of available spring forages when crimson clover was overseeded into bahiagrass pasture as compared to the same pasture managed with commercial nitrogen fertilizer in Americus, Georgia. Poor performance of berseem clover at both study sites could be due to soil type (sandy and light clay). Farmers may want to incorporate this forage in pastures with suitable soils (moist clay) (Ball et al., 2007 ) as this forage was well grazed by goats. Forage 
combination in all treatments showed good quality with low fiber (ADF, 194-241 $\mathrm{g} \mathrm{kg}^{-1}$ ) and moderate to high protein (CP, 115-170 $\mathrm{g} \mathrm{kg}^{-1}$ ).

The economic benefit associated with developing winter pastures and their sustainable grazing management found in the current study was tremendous (Selma, \$1,537; Phenix City, \$1,431). The overall benefits would be even higher when possible improvements in soil quality, biodiversity, erosion control and support for wildlife are accounted for as a result of pasture improvement and sustainable grazing management. A previous study (Karki et al., 2009) showed that incorporation of crimson clover in bahiagrass pastures improved soil quality with reduced penetration resistance and increased water-stable aggregates as compared to the same pasture managed with nitrogen fertilizer application. The economic benefits of improved pastures and grazing is also emphasized by Hancock (2012), who found $20 \%$ or higher increment in the net farm incomes of pasture-based livestock operators after participating in Grazing School.

\section{Conclusion}

The current study identified five legumes that can be grown in combination with Marshall ryegrass to develop winter pastures for goats. However, producers need to be cautioned on winter peas, which required some time for goats to get used to. The mixtures of crimson clover and Marshall ryegrass and hairy vetch and Marshall ryegrass produced the greatest biomass among the legume-grass combinations. Study showed significant economic benefits $(\$ 1,537.00$, Selma; $\$ 1,431.00$, Phenix City) of developing winter pastures for goats. Forages and their combinations identified from this study can be used to improve goat pastures provided the suitable soil type and climatic conditions. Pasture improvement and sustainable grazing management will be helpful to reduce production costs, promote animal health and wellbeing and enhance the sustainability of pasture-based goat operations. Extension educators can use the findings of the current research to educate goat producers in order to make their operations more sustainable.

\section{Acknowledgement}

This study was funded by Southern Sustainable Agriculture Research and Education, On-Farm Research Grant \#OS11-059 and 1890 Extension Formula Grant. Authors are thankful for the help and cooperation provided by the cooperator goat producers: Gregory Scott from Selma and Nimrod Stephens from Phenix City, Alabama, United States.

\section{Author's Contributions}

Uma Karki: Designed and implemented the research, collected and analyzed data and developed the manuscript on animals, forage and soil portions.

Lila Bahadur Karki: Designed and implemented the research, collected and analyzed data and developed the manuscript on economic portion.

\section{Ethics/Conflict of Interest}

The findings presented in this manuscript are fully based on the scientific evidence and not influenced by any financial gain or personal relationship.

\section{References}

Ball, D.M., C.S. Hoveland and G.D. Lacefield, 2007. Southern Forages: Modern Concepts for Forage Crop Management. 1st Edn., Potash and Phosphate Institute and the Foundation for Agronomic Research, Norcross, ISBN-10: 0962959863, pp: 322.

Goering, H.K. and P.J. Van Soest, 1970. Forage Fiber Analyses (Apparatus, Reagents, Procedures and Some Applications). 1st Edn., U.S. Agricultural Research Service, Washington, pp: 20.

Jones, K., 2003. Meat goats: A growing industry. Economic Research Service, USDA.

Hancock, D.W., 2012. Grazing schools improve the sustainability of pasture-based livestock enterprises. J. Extension.

Kallenbach, R., 2000. Reducing losses when feeding hay to beef cattle. University Missouri-Columbia.

Karki, U., M.S. Goodman and S.E. Sladden, 2009. Nitrogen source influences on forage and soil in young southernpine silvopasture. Agric. Ecosyst. Environ., 131: 70-76. DOI: 10.1016/j.agee.2008.09.007

Kebede, E., 2005. Goat meat demand in the U.S. and goat meat marketing potential in the southeast: George Washington carver agricultural experiment station. Tuskegee University.

Littell, R.C., G.A. Milliken, W.W. Stroup, R.D. Wolfinger and O. Schabenberger, 2006. SAS for Mixed Models. 2nd Edn., SAS Institute, Cary, ISBN-10: 1599940787, pp: 828.

Solaiman, S.G., 2007. Comparing goat production economics on different production systems in the Southeastern U.S.

USCB, 2012. U.S. Census Bureau projections show a slower growing, older, more diverse nation a half century from now.

USDA-ERS, 2013. Fertilizer use and price. United States Department Agricultural Economic Research Service. 